\title{
Biochar Application Improves Soil Respiration and Nitrogen Miner- alization in Alkaline Calcareous Soil under Two Cropping Systems
}

\author{
Tasneem Shah*, Muhammad Tariq and Dost Muhammad
}

Department of Soil and Environmental Sciences, The University of Agriculture, Peshawar, Khyber Pakhtunkhwa, Pakistan.

\begin{abstract}
Biochar can be used as a strategy to facilitate $\mathrm{C}$ and $\mathrm{N}$ sequestration in less fertile soil. Surface soil samples from a 4 years long field experiment were collected to assess the effect of added biochar $(0,50,90$ and $130 \mathrm{t} \mathrm{ha}^{-1}$ ) and chemical fertilizers (viz., urea for $\mathrm{N}$, single superphosphate for $\mathrm{P}$ and potassium chloride for $\mathrm{K}$ ) on soil respiration and $\mathrm{N}$ mineralization during lab incubation experiment under wheat-mungbean and wheat-maize cropping systems. The rate of $\mathrm{CO}_{2}$ evolution increased significantly $(\mathrm{P}<0.05)$ with increasing level of added biochar during each incubation period. At day 2, the rate of $\mathrm{CO}_{2}$ evolution increased from $142 \mu \mathrm{g} \mathrm{CO} \mathrm{g}^{-1}$ soil d $\mathrm{d}^{-1}$ in the control to $259 \mu \mathrm{g} \mathrm{CO}_{2} \mathrm{~g}^{-1}$ soil $\mathrm{d}^{-1}$ in the treatment receiving $130 \mathrm{t}$ biochar $\mathrm{ha}^{-1}$. The same trend continued during 4,8 and 16 days of incubation periods. However, the rate of $\mathrm{CO}_{2}$ evolution declined over time in each treatment. The effect of mineral fertilizers and cropping systems on $\mathrm{CO}_{2}$ evolution were statistically non-significant $(\mathrm{P}<0.05)$. The response of cumulative $\mathrm{CO}_{2}$ production to biochar, mineral fertilizers and cropping systems was almost similar to rate of $\mathrm{CO}_{2}$ production. The data on net $\mathrm{N}$ mineralization revealed that maximum $\mathrm{N}$ mineralization was observed for the treatment which had received biochar at $90 \mathrm{t} \mathrm{ha}^{-1}$ over the last few years whereas the differences between the control (no biochar), lower biochar $\left(50 \mathrm{t} \mathrm{ha}^{-1}\right)$ treatments and highest biochar $\left(130 \mathrm{t} \mathrm{ha}^{-1}\right)$ treatment were statistically non-significant during 7,14 and 28 days of incubation periods. Nitrogen mineralization did not vary significantly among the mineral fertilizers or cropping systems treatments. Moreover, the interactive effects of cropping systems $\mathrm{x}$ biochar, and cropping systems $\mathrm{x}$ mineral fertilizers were significant for $\mathrm{CO}_{2}$ efflux and $\mathrm{N}$ mineralization at least during the first 2 days of incubation period. These results suggest that biochar amendment enhanced $\mathrm{CO}_{2}$ evolution during short-term incubation period (i.e., 16 days) suggesting the availability of labile $\mathrm{C}$ pool in the added biochar which serve as a source of energy for promotion of microbial activity in the soil. The low net $\mathrm{N}$ mineralization in the high biochar treatment implies that biochar could be used as a strategy to minimize $\mathrm{N}$ losses from the easily available labile $\mathrm{N}$ pools through greater $\mathrm{N}$ retention in soil.

Received | September 03, 2020; Accepted | November 17, 2020; Published | May 03, 2021

*Correspondence | Tasneem Shah, Department of Soil and Environmental Sciences, The University of Agriculture, Peshawar, Khyber Pakhtunkhwa, Pakistan; Email: tasneemshah92@gmail.com

Citation | Shah, T., M. Tariq and D. Muhammad. 2020. Biochar application improves soil respiration and nitrogen mineralization in alkaline calcareous soil under two cropping systems. Sarbad Journal of Agriculture, 37(2): 500-510.

DOI | https://dx.doi.org/10.17582/journal.sja/2021/37.2.500.510

Keywords $\mid$ Biochar, $\mathrm{C}$ and $\mathrm{N}$ sequestration, $\mathrm{CO}_{2}$ evolution, Alkaline calcareous soil, Low soil fertility
\end{abstract}

\section{Introduction}

Soil respiration and nitrogen mineralization are Nimportant microbiological processes and are the key indicators of soil health. Soil respiration is a microbiological process where microorganisms decomposes organic matter and releases carbon in the form of carbon dioxide $\left(\mathrm{CO}_{2}\right)$. Soil respiration produces a major flux of $\mathrm{CO}_{2}$, emitting over 10 times more $\mathrm{CO}_{2}$ per year to the atmosphere than combustion 
of fossil fuel as reported in Phillips and Nickers (2015). Soil respiration thus contribute substantially to the green house gases in the atmosphere in the form $\mathrm{CO}_{2}$. It also indicates the level of soil fertility and microbial activity occurring in the soil. More $\mathrm{CO}_{2}$ evolution means more organic matter and its decomposition in the soil. Thus, soils with greater soil respiration is an indicator where the soils are more fertile and active in microbial action and more supportive to plant growth and all kinds of soil life.

Nitrogen mineralization is another important process where unavailable organic nitrogen is converted into plant available nitrogen as ammonium $\left(\mathrm{NH}_{4}\right)$ and nitrate $\left(\mathrm{NO}_{3}\right)$ through the action of soil microorganisms. Since plants can only absorb nitrogen in the form of $\mathrm{NH}_{4}$ and $\mathrm{NO}_{3}, \mathrm{~N}$ mineralization contributes significantly to support crop growth. Large amount of nitrogen in soil is present in organic form (organic matter, crop residues, manures etc.) but become available only after mineralization. Depending on various factors, the release of mineral $\mathrm{N}$ from organic $\mathrm{N}$ may be predicted. It is therefore important to understand such prediction in a given growing season as it is necessary to calculate correct doses of fertilizers application. Knowing the rate of nitrogen mineralization from organic amendments including manures, crop residues, organic wastes and soil organic matters during a given growing season would enable you to predict correct dose of fertilizer $\mathrm{N}$ application. In this way over or lower application of fertilizer $\mathrm{N}$ can be avoided. According to a report in Barker (2011), N mineralization may contribute from $15-50 \mathrm{~kg} \mathrm{~N} \mathrm{ha}{ }^{-1}$ in the top $0-15 \mathrm{~cm}$ of soil during a typical growing season. For soils with high organic matter contents under no-till and following legumes based crop system, the contribution of $\mathrm{N}$ from mineralization could be much greater than $50 \mathrm{~kg} \mathrm{ha}^{-1}$.

Soil respiration and $\mathrm{N}$ mineralization are generally limited in soils low in organic matter. Application of organic amendments promotes both the processes. Among organic amendments, biochar contain carbon which is resistant to decomposition and can provide a long-term support to soil microorganisms. Biochar is thus promoted as a soil amendment to enhance soil microbial processes necessary for maintaining and improving soil quality. Biochar is also seen as a source of long-term sequestration of carbon that help increasing soil quality and reduce $\mathrm{CO}_{2}$ evolution to the atmosphere (Laird, 2008; Novak et al., 2010). The biochar can influence $\mathrm{C}$ and $\mathrm{N}$ losses by controlling their cycles and can improve physicochemical properties of soils (Lehmann et al., 2011). Ameloot et al. (2013) reported that mineralization activity was higher during the first few days after the biochar amendment after which the respiration rates become similar to non-amended soil. The effect of biochar however varies with the type of biochar depending on how biochar is prepared (Amonette et al., 2008). Although biochar application to soils has a significant influence on soil respiration and emission of other gases $\left(\mathrm{N}_{2} \mathrm{O}\right.$ and $\left.\mathrm{CH}_{4}\right)$, there have been no consistent results regarding the response of such processes to biochar application. Biochar amendments resulted in enhanced evolution of $\mathrm{CO}_{2}$ in some studies as of Kammann et al. (2012), Zheng et al. (2012), Shah et al. (2017) and others. The results of Rondon et al. (2005) and several others (Liu et al., 2011; Dempster et al., 2012; Fabbri et al., 2013; Malghani et al., 2013) revealed that biochar amendments decreased $\mathrm{CO}_{2}$ emission from soil. In addition to $\mathrm{CO}_{2}$ evolution, biochar can also influence $\mathrm{N}$ transformations (Anderson et al., 2011). Nelissen et al. (2012) reported increase in net mineralization of $\mathrm{N}$ in soil after biochar amendment. In other studies, biochar application increased the process of nitrification (e.g. Song et al., 2014) and denitrification in soil (Cayuela et al., 2013).

Although the potential benefits of biochar application was observed in previous studies for soil fertility and crop growth, the reports have been inconsistent depending on type of biochar and soil and environmental conditions. Moreover, there is a lack of understanding of the interactions of biochar application with different microbiological processes in the soil. This study was therefore, undertaken to improve our understanding regarding the effect of biochar application on soil respiration $\left(\mathrm{CO}_{2}\right)$ and $\mathrm{N}$ mineralization in an alkaline calcareous soil in the semi arid environment.

\section{Materials and Methods}

\section{Site characterization}

The experiment was conducted at the University of Agriculture, Peshawar, Pakistan $\left(34.01^{\circ} \mathrm{N}, 71.50^{\circ} \mathrm{E}\right)$. The surface soil of the experimental site was classified as silty clay loam and fine mixed, hypothermic, alkaline astochrepths belong to the Pirsabak soil series. The soil was non-saline $\left(<2.00 \mathrm{dS} \mathrm{m}^{-1}\right)$, alkaline ( $\left.\mathrm{pH} 8.0\right)$, strongly calcareous $(17.5 \%)$ and low in soil fertility 
(organic matter $<1.0 \%$, total $\mathrm{N} 0.07 \%$, AB-DTPA extractable P $3.0 \mathrm{mg} \mathrm{kg}^{-1}$ soil) (Shafi et al., 2007). The agroclimatic conditions are semi-arid climate with a mean rainfall in the region is about $380 \mathrm{~mm}_{\text {year }}^{-1}$ and that vary considerably from season to season. The wet season is between February and September with peak rainfall mostly occurs in February-April and JulySeptember. October through January are mostly the dry months. The hot season lasts for about 4 months from mid May to mid September, with an average daily high temperature above $97^{\circ} \mathrm{F}\left(36^{\circ} \mathrm{C}\right)$. The cool season last for 3 months, from early December to early March, with an average daily high temperature below $69^{\circ} \mathrm{F}\left(20^{\circ} \mathrm{C}\right)$.

\section{Trial description}

This study was conducted in a field trial which was started back in November 2014 with wheat cropping. The aim of the field was to determine the effects of biochar application on crop yields and soil properties under different cropping systems in the long term. Randomized complete block design with split-split plot arrangements was used in the trial. There were four replications. The experiment was comprised of two cropping systems, two chemical fertilizer treatment, four biochar levels and four replications, thus having 64 treatment plots altogether. The main plots were assigned to cropping systems, sub-plots to chemical fertilizers (full recommended NPK and $1 / 2$ of recommended NPK) and sub-sub-plots to biochar levels. Chemical fertilizers were applied in the form of urea $(\mathrm{N})$, single superphosphate $(\mathrm{P})$ and potassium chloride (K). So far, the experiment had received various levels of biochar ( $\left.\mathrm{t} \mathrm{ha}^{-1}\right)$ viz., 0 (T1), 50 (T2), 90 (T3) and 130 (T4) over the past four years. Biochar used in the experiment was derived from Acacia sp. through pyrolysis temperature over $400{ }^{\circ} \mathrm{C}$ and obtained from the market. For this study, the surface 0-15 cm soil samples were sampled from all treatment plots after harvest of wheat crop, when the field was being prepared for summer crops (maize, mungbean) but before application of any amendments in the first week of July 2018. Two cropping systems viz., wheat-mungbean and wheat-maize were selected for this study. Wheat was sown in the second week of November and harvested in third week of May every year. Maize and mungbean were planted in second week of July and harvested in second and third week of September each year. Composite soil samples of each treatment plot were processed immediately after collection. After removing stones and large plant residues, the soil samples were sieved $<2-\mathrm{mm}$ sieve) while still moist. The soil samples after proper homogenization of individual treatments were stored in a safe place until before the incubation experiments.

\section{Measurement of soil respiration ( $\mathrm{CO}_{2}$ evolution)}

The soil samples while still moist were analyzed for $\mathrm{CO}_{2}$ evolution following the alkali trapping procedure (Shah et al.,2010).For determination of $\mathrm{CO}_{2}$ evolution, $50 \mathrm{~g}$ moist soil sample, in duplicate, was transferred to a clean $500 \mathrm{~mL}$ conical flask and a vial with $5 \mathrm{ml}$ of $0.3 \mathrm{M} \mathrm{NaOH}$ solution was suspended in the flask. After proper sealing using rubber bungs, the samples were incubated at $25^{\circ} \mathrm{C}$ in the incubator on 23 July 2018. After 2 days on 25 July, the flasks were taken out and the $\mathrm{NaOH}$ solution of the vial was titrated with $0.1 \mathrm{~N} \mathrm{HCl}$ in the presence of barium chloride solution $(1 \mathrm{M} 10 \mathrm{ml})$ and phenolphthalein indicator till reaching the end point. The amount $\mathrm{HCl}$ used was taken as a measure of $\mathrm{CO}_{2}$ evolved during the given incubation period. The vials were refilled with fresh $5 \mathrm{ml} 0.3 \mathrm{M} \mathrm{NaOH}$ solution and suspended in the flask, and the samples were incubated again under similar conditions. The process of $\mathrm{CO}_{2}$ measurement was repeated similarly after $4 \mathrm{~d}\left(27^{\text {th }}\right.$ July), $8 \mathrm{~d}\left(31^{\text {st }}\right.$ July) and $16 \mathrm{~d}$ ( $8^{\text {th }}$ August 2018) of incubation. The $\mathrm{CO}_{2}$ produced was expressed both as rate $\left(\mu \mathrm{g} \mathrm{CO}_{2} \mathrm{~g}^{-1}\right.$ soil day ${ }^{-1}$ ) as well as cumulative amount for the given incubation periods ( $\mu \mathrm{g} \mathrm{CO}_{2} \mathrm{~g}^{-1}$ soil produced during the given incubation period).

\section{Measurement of $N$ mineralization}

Nitrogen mineralization was also measured in same soil samples run for measurement of soil respiration. For measurement of $\mathrm{N}$ mineralization, $500 \mathrm{~g}$ moist soil samples of each treatment plot were taken in individual incubation pots, in duplicate, and incubated at $25^{\circ} \mathrm{C}$ in the incubator on 13 August 2018. The soil samples were analysed for total mineral $\mathrm{N}$ at day 0 on 13 August 2018 and subsequently on 20 August after 7 days, 27 August after 14 days and on 10 September 2018 after 28 days of incubation periods. Moisture contents were also measured at each incubation period. Soil samples were regularly stirred and watered when needed to maintain field moisture condition in the incubated samples. Net $\mathrm{N}$ mineralization ( $\mu \mathrm{g} \mathrm{Ng}^{-1}$ soil) in soil samples was calculated by removing the mineral $\mathrm{N}$ at day 0 from that obtained after incubations i.e., at day 7, 14 and 28. 
Determination of total mineral $N$ in soil

Total mineral $\mathrm{N}$ in soil samples was determined following the procedure described in Mulvaney (1996). For this, $20 \mathrm{~g}$ moist soil sample was aggressively shaken with $100 \mathrm{ml}$ of $1 \mathrm{M} \mathrm{KCl}$ in a $250 \mathrm{ml}$ shaking bottles using end-to-end horizontal shaker for one hour. After allowing the sediment to settle down, carefully filtered the suspension. Twenty $\mathrm{ml}$ of the filterate was distilled with $0.2 \mathrm{~g}$ each of $\mathrm{MgO}$ and Devarda's alloy into $5 \mathrm{ml}$ indicator solution containing boric acid, methyl red and Bromo cresol green indicators for about 10 minutes followed by titration with $0.005 \mathrm{~N} \mathrm{HCl}$. The amount of $\mathrm{HCl}$ used in titration was taken as a measure of the amount of mineral $\mathrm{N}\left(\mathrm{NH}_{4}-\mathrm{N}\right.$ and $\left.\mathrm{NO}_{3}-\mathrm{N}\right)$ in the sample.

\section{Statistical analysis}

Statistical analysis of the data was carried out using appropriate statistical package following the principles described in Steel et al. (1997). The LSD tests were used to determine statistical differences between treatments at 5\% level of probability.

\section{Results and Discussion}

Surface soil samples from a 4 year long field experiment was collected to assess the effect of biochar and chemical fertilizers $(\mathrm{N}, \mathrm{P}$ and $\mathrm{K})$ on soil respiration and $\mathrm{N}$ mineralization during lab incubation experiment under wheat-mungbean and wheat-maize cropping systems. The results obtained are presented and discussed below:

\section{Soil respiration}

The results obtained on soil respiration are expressed as rate of $\mathrm{CO}_{2}$ evolution and cumulative $\mathrm{CO}_{2}$ production and presented below:

\section{Rate of $\mathrm{CO}_{2}$ production}

It was observed from the data that the rate of $\mathrm{CO}_{2}$ evolution increased significantly $(\mathrm{P}<0.05)$ with increasing level of added biochar during each incubation period as reflected in Table 1. At day 2, the rate of $\mathrm{CO}_{2}$ evolution increased from $142 \mu \mathrm{g} \mathrm{CO}$ $\mathrm{g}^{-1}$ soil d $\mathrm{d}^{-1}$ in the control to $259 \mu \mathrm{g} \mathrm{CO}_{2} \mathrm{~g}^{-1}$ soil d $\mathrm{d}^{-1}$ in the treatment receiving $130 \mathrm{t}$ biochar ha ${ }^{-1}$. The same trend continued during other incubation periods. It was observed that the rate of $\mathrm{CO}_{2}$ evolution in each treatment was greater during earlier incubation periods and the rate decreased with increasing incubation period. The rate of $\mathrm{CO}_{2}$ evolution declined from $142 \mu \mathrm{g}$ at day 2 to $34 \mu \mathrm{g} \mathrm{CO} \mathrm{g}^{-1}$ soil d ${ }^{-1}$ at day 16 in the control, and from $259 \mu \mathrm{g}$ at day 2 to 44 $\mu \mathrm{g} \mathrm{CO}_{2} \mathrm{~g}^{-1}$ soil $\mathrm{d}^{-1}$ at day 16 in treatment receiving the highest biochar level. However, differences among treatments were significant at each incubation period. With respect to mineral fertilizer treatments, no significant differences in $\mathrm{CO}_{2}$ evolution were observed between $1 / 2$ NPK and full NPK treatments. It was noticed that although non-significant, the rate of $\mathrm{CO}_{2}$ evolution was consistently greater for full than $1 / 2$ NPK treatment (Table 1). Similarly, differences in $\mathrm{CO}_{2}$ evolution between the wheat-mungbean and wheat-maize cropping system were not significant (Table 1). Generally, the rate of $\mathrm{CO}_{2}$ evolution in the mungbean based cropping system was greater during 2 and 4 days incubation suggesting the presence of easily decomposable organic materials.

Table 1: Rate of $\mathrm{CO}_{2}$ production as affected by biochar application and chemical fertilizers under wheat-mung and wheat-maize cropping systems. Biochar levels are cumulative amount added over the last five years. Full $N P K$ means recommended doses of NPK for the given crops while $1 / 2$ NPK means $1 / 2$ of the same recommended NPK doses.

\begin{tabular}{|c|c|c|c|c|c|}
\hline \multicolumn{2}{|l|}{ Treatment } & \multicolumn{4}{|c|}{$\begin{array}{l}\mathrm{CO}_{2} \mu \mathrm{g} \mathrm{g}^{-1} \text { soil } \mathrm{d}^{-1} \text { during } \\
\text { incubation at }\end{array}$} \\
\hline \multirow[t]{6}{*}{ Biochar (BC) } & $\operatorname{Level}\left(\mathrm{t} \mathrm{ha}^{-1}\right)$ & Day 2 & Day 4 & Day 8 & Day 16 \\
\hline & 0 & 142 & 112 & 58 & 34 \\
\hline & 50 & 149 & 135 & 57 & 30 \\
\hline & 90 & 205 & 198 & 83 & 44 \\
\hline & 130 & 259 & 244 & 102 & 44 \\
\hline & Significance & $*$ & $*$ & * & $*$ \\
\hline \multirow{3}{*}{$\begin{array}{l}\text { Chemical ferti- } \\
\text { lizers }(\mathrm{CF})\end{array}$} & 1/2 NPK & 187 & 168 & 71 & 36 \\
\hline & Full NPK & 190 & 177 & 79 & 40 \\
\hline & Significance & ns & ns & ns & ns \\
\hline \multirow{3}{*}{$\begin{array}{l}\text { Cropping sys- } \\
\text { tems (CS) }\end{array}$} & Wheat-mung & 194 & 180 & 70 & 37 \\
\hline & Wheat-maize & 183 & 164 & 80 & 39 \\
\hline & Significance & ns & ns & ns & ns \\
\hline \multicolumn{6}{|l|}{ Interactions } \\
\hline & $\mathrm{BC} \times \mathrm{CF}$ & ns & $\mathrm{ns}$ & ns & ns \\
\hline & $\mathrm{CS}_{\mathrm{x}} \mathrm{CF}$ & $*$ & $*$ & $*$ & $*$ \\
\hline & $\mathrm{CS} \times \mathrm{BC}$ & Fig. 1 & ns & ns & ns \\
\hline & $\mathrm{CS} \times \mathrm{BC} \times \mathrm{CF}$ & $*$ & ns & ns & ns \\
\hline
\end{tabular}

The interactions between cropping systems and mineral fertilizers were significant during all 
incubation period (Table 1). It was noticed that the rate of $\mathrm{CO}_{2}$ evolution was remarkably greater for full NPK relative to $1 / 2 \mathrm{NPK}$ treatment in soil taken from wheat-maize cropping system relative to wheatmungbean cropping system. The same trend continued during 2, 4, 8 and 8 days of incubation period (Table 1). It appears that mineral fertilizer application was more effective in continuous cereal cropping relative to that having legume in the rotation. Moreover, the interaction between cropping system and biochar was also significant during the first 2 days of incubation period (Figure 1). We noticed that the rate of carbon dioxide efflux was greater for mungbean based cropping system in the control or in low biochar treatment. With increasing biochar level, the rate of $\mathrm{CO}_{2}$ evolution elevated for cereal based cropping system suggesting that biochar become more effective under cereal-cereal cropping system.

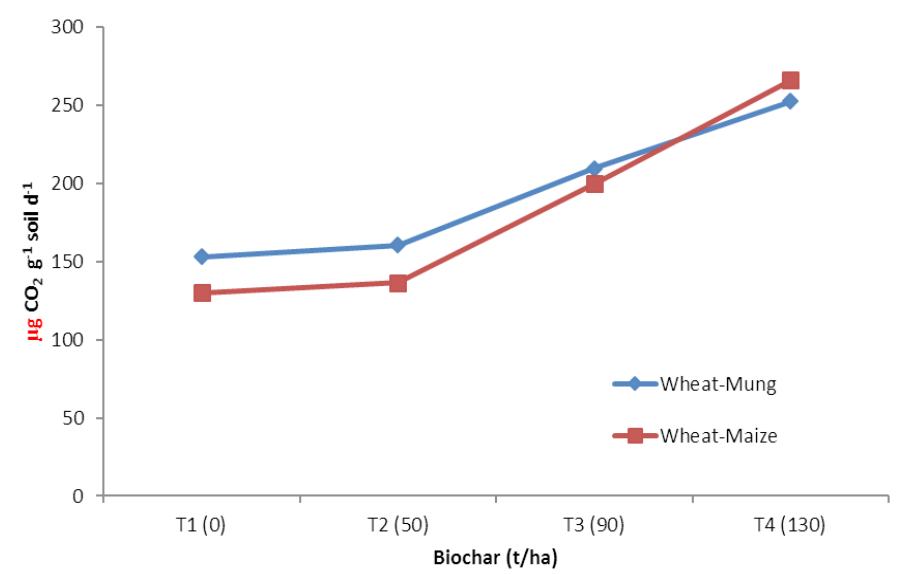

Figure 1: Interactive effect of cropping systems and biochar levels on rate of $\mathrm{CO}_{2}$ production during the first 2 days of incubation period.

\section{Cumulative $\mathrm{CO}_{2}$ production}

The data revealed that cumulative $\mathrm{CO}_{2}$ production was affected considerably by the biochar treatment during each incubation period (Table 2). The $\mathrm{CO}_{2}$ production increased as the level of added biochar increased. Almost the same trend was observed at each incubation period. As evident in Table 2, the total $\mathrm{CO}_{2}$ production during the first 2 days increased from $283 \mu \mathrm{g} \mathrm{CO} \mathrm{g}^{-1}$ soil in the control to $519 \mu \mathrm{g} \mathrm{CO}$ $\mathrm{g}^{-1}$ soil in treatment receiving the highest amount of biochar. The corresponding values during 16 days of incubations were $1073 \mu \mathrm{g} \mathrm{CO} \mathrm{g}^{-1}$ soil in the control and $1866 \mu \mathrm{g} \mathrm{CO} \mathrm{g}^{-1}$ soil in treatment receiving the highest amount of biochar. This correspond to $83 \%$ in $\mathrm{CO}_{2}$ during the first 2 days and $74 \%$ increase during 16 days of incubation due to higher doses of biochar application. With respect to influence of mineral fertilizers treatment, $\mathrm{CO}_{2}$ production was insignificant but consistently greater for full than $1 / 2$ NPK treatment during all four incubation periods. However, no remarkable differences between the $1 / 2$ and full NPK treatments were noticed. We found that $\mathrm{CO}_{2}$ production was initially high in the mungbean bases cropping system compared with cereal based cropping system. However, differences in $\mathrm{CO}_{2}$ production between the two cropping systems were statistically non-significant $(\mathrm{P}<0.05)$.

Table 2: Cumulative $\mathrm{CO}_{2}$ production as affected by biochar application and chemical fertilizers under wheatmung and wheat-maize cropping systems. Biochar levels are cumulative amount added over the last five years. Full $N P K$ means recommended doses of NPK for the given crops while $1 / 2 N P K$ means $1 / 2$ of the same recommended NPK doses.

\begin{tabular}{|c|c|c|c|c|c|}
\hline \multirow{2}{*}{$\begin{array}{l}\text { Treatment } \\
\text { Biochar (BC) }\end{array}$} & \multirow[b]{2}{*}{ Level $\left(\mathrm{t} \mathrm{ha}^{-1}\right)$} & \multicolumn{4}{|c|}{$\begin{array}{l}\mathrm{CO}_{2} \mu \mathrm{g} \mathrm{g}^{-1} \text { soil during given } \\
\text { incubation period }\end{array}$} \\
\hline & & Day 2 & Day 4 & Day 8 & Day 16 \\
\hline & 0 & 283 & 507 & 797 & 1073 \\
\hline & 50 & 297 & 567 & 854 & 1098 \\
\hline & 90 & 409 & 805 & 1219 & 1568 \\
\hline & 130 & 519 & 1007 & 1516 & 1866 \\
\hline & Significance & $*$ & $*$ & $*$ & * \\
\hline \multirow{3}{*}{$\begin{array}{l}\text { Chemical fer- } \\
\text { tilizers (CF) }\end{array}$} & $1 / 2 \mathrm{NPK}$ & 374 & 710 & 1067 & 1357 \\
\hline & Full NPK & 380 & 733 & 1125 & 1445 \\
\hline & Significance & ns & ns & ns & ns \\
\hline \multirow{3}{*}{$\begin{array}{l}\text { Cropping } \\
\text { systems (CS) }\end{array}$} & Wheat-mung & 388 & 748 & 1099 & 1399 \\
\hline & Wheat-maize & 366 & 695 & 1094 & 1403 \\
\hline & Significance & ns & ns & ns & ns \\
\hline \multicolumn{6}{|l|}{ Interactions } \\
\hline & $\mathrm{BC} \times \mathrm{CF}$ & $\mathrm{ns}$ & ns & ns & ns \\
\hline & $\mathrm{CS} \times \mathrm{CF}$ & $*$ & ns & ns & ns \\
\hline & $\mathrm{CS} \times \mathrm{BC}$ & Fig. 2 & $*$ & $*$ & $*$ \\
\hline & $\mathrm{CS} \times \mathrm{BC} \times \mathrm{CF}$ & $*$ & ns & ns & ns \\
\hline
\end{tabular}

The interactive effect of cropping system $\mathrm{x}$ biochar on cumulative $\mathrm{CO}_{2}$ production was significant initially only (2 days incubation period) (Table 2). Furthermore, the cumulative $\mathrm{CO}_{2}$ production was higher for cropping system having mungbean in the rotation relative to that having continuous cereal in the rotation and where there was nil or receiving lower doses of biochar (Figure 2). At increasing biochar level, $\mathrm{CO}_{2}$ production get leveled or become higher in wheat-maize than wheat-mungbean cropping system. These results suggest that mungbean residue 
decomposes quickly and produces greater $\mathrm{CO}_{2}$ in the absence of biochar. It looks that most of the $\mathrm{CO}_{2}$ is coming from biochar under wheat-maize cropping system. The interactions between cropping systems and mineral fertilizers for $\mathrm{CO}_{2}$ production were found significant during all four incubation periods (Table 2). The differences in $\mathrm{CO}_{2}$ production were insignificant between $1 / 2$ and NPK doses under wheat-mungbean cropping system but become highly significant under wheat-maize cropping system during the first 2 days and subsequently same trend was observed during 4 , 8 and 16 (Table 4) days of incubation periods. These results suggest that mineral fertilizers application increases $\mathrm{CO}_{2}$ only under cereal-cereal cropping system.

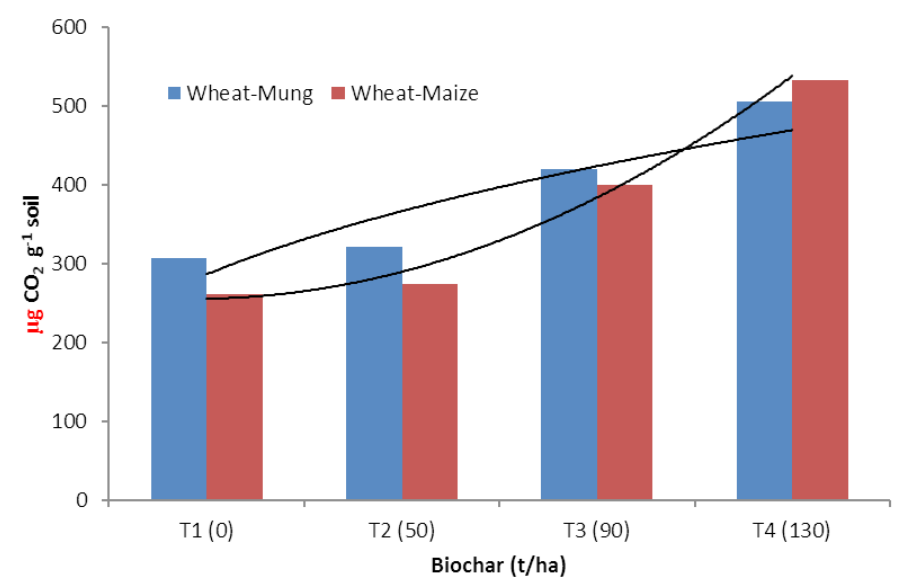

Figure 2: Interactive effect of cropping systems and biochar levels on cumulative $\mathrm{CO}_{2}$ production during the first 2 days of incubation period.

\section{Nitrogen mineralization}

The data obtained on gross and net $\mathrm{N}$ mineralization in soil collected from biochar and mineral fertilizers amended treatments under different cropping systems are presented in Tables 3 and 4, respectively. The data revealed that $\mathrm{N}$ mineralization differed significantly among the biochar amended treatments particularly during the first few days of incubation periods. At day 0 , the highest mineral $\mathrm{N}$ contents were obtained for treatment receiving the highest amount of biochar. Differences between control and low biochar treatments were statistically non-significant during the 0,7 and 14 days of incubation period. At day 28 , no considerable differences in $\mathrm{N}$ mineralization were obtained among biochar treatments (Table 3). Moreover, the differences in $\mathrm{N}$ mineralization between the $1 / 2$ and full NPK treatments were not significant, and there was no specific pattern in $\mathrm{N}$ mineralization during any of the four incubation periods (Table 3). Similarly, differences in $\mathrm{N}$ mineralization between the wheat-mungbean and wheat-maize cropping systems were not significant during any of the four incubation periods (Table 3). Like mineral fertilizer treatments, no specific pattern in $\mathrm{N}$ mineralization was observed during any of the four incubation periods.

Table 3: Gross $N$ mineralization as affected by biochar application and chemical fertilizers under wheat-mung and wheat-maize cropping systems. Biochar levels are cumulative amount added over the last five years. Full $N P K$ means recommended doses of NPK for the given crops while $1 / 2$ NPK means $1 / 2$ of the same recommended NPK doses.

\begin{tabular}{|c|c|c|c|c|c|}
\hline Treatment & \multirow[b]{2}{*}{ Level $\left(\mathrm{t} \mathrm{ha}^{-1}\right)$} & \multicolumn{4}{|c|}{$\mu \mathrm{g} \mathrm{N} \mathrm{g}^{-1}$ soil during incubation } \\
\hline \multirow[t]{6}{*}{ Biochar (BC) } & & Day 0 & Day 7 & Day 14 & Day 28 \\
\hline & 0 & 7.60 & 10.66 & 11.32 & 18.23 \\
\hline & 50 & 8.64 & 12.47 & 12.14 & 19.69 \\
\hline & 90 & 6.40 & 13.89 & 14.33 & 21.58 \\
\hline & 130 & 10.13 & 13.53 & 13.84 & 18.16 \\
\hline & Significance & $*$ & $*$ & $*$ & ns \\
\hline \multirow{3}{*}{$\begin{array}{l}\text { Chemical fer- } \\
\text { tilizers (CF) }\end{array}$} & $1 / 2 \mathrm{NPK}$ & 8.86 & 12.33 & 12.50 & 19.87 \\
\hline & Full NPK & 7.52 & 12.94 & 13.32 & 18.96 \\
\hline & Significance & ns & ns & ns & ns \\
\hline \multirow{3}{*}{$\begin{array}{l}\text { Cropping } \\
\text { systems (CS) }\end{array}$} & Wheat-mung & 8.65 & 13.05 & 10.88 & 20.31 \\
\hline & Wheat-maize & 7.74 & 12.22 & 14.93 & 18.52 \\
\hline & Significance & ns & ns & ns & ns \\
\hline \multicolumn{6}{|l|}{ Interactions } \\
\hline & $\mathrm{BC} \times \mathrm{CF}$ & ns & ns & ns & ns \\
\hline & $\mathrm{CS} \times \mathrm{CF}$ & $*$ & $*$ & $*$ & $*$ \\
\hline & $\mathrm{CS} \times \mathrm{BC}$ & * & $*$ & $\mathrm{~ns}$ & ns \\
\hline & $\mathrm{CxBCxCF}$ & ns & ns & $\mathrm{ns}$ & ns \\
\hline
\end{tabular}

The interactions between biochar and cropping systems for gross $\mathrm{N}$ mineralization were found significant $(\mathrm{P}<0.05)$ during 0,7 and 28 days of incubation periods (Table 3 ). The data indicated that gross $\mathrm{N}$ mineralization was greater in soil under wheatmungbean cropping system when no or lowers doses of biochar were applied during 0 day of incubation period. At higher doses of biochar, $\mathrm{N}$ mineralization was greater in soil under wheat-maize cropping system. Exactly the same trend for $\mathrm{N}$ mineralization was observed during 7 and 28 days of incubation periods asevident in Table 3. The interactions between cropping systems and mineral fertilizer treatments for gross $\mathrm{N}$ mineralization were found significant during the first 3 incubation periods. Table 3 further indicated that gross $\mathrm{N}$ mineralization was significantly greater 
for full NPK treatment compared with $1 / 2$ NPK treatment under wheat mungbean cropping system during 0 day incubation period. For wheat-maize cropping system, $\mathrm{N}$ mineralization was either leveled or slighter greater in full than $1 / 2 \mathrm{NPK}$ treatment during 0 day incubation period. Almost the same trend for $\mathrm{N}$ mineralization was observed at day 7 and 14 days of incubation periods. It was visible from the data that $\mathrm{N}$ mineralization was remarkably greater for wheat-maize than wheat-mungbean cropping systems during all incubation periods.

Table 4: Net $N$ mineralization as affected by biochar application and chemical fertilizers under wheat-mung and wheat-maize cropping systems. Biochar levels are cumulative amount added over the last five years. Full $N P K$ means recommended doses of NPK for the given crops while $1 / 2$ NPK means $1 / 2$ of the same recommended NPK doses.

Treatment

\begin{tabular}{|c|c|c|c|c|}
\hline \multirow[t]{6}{*}{ Biochar (BC) } & $\operatorname{Level}\left(\mathrm{t} \mathrm{ha}^{-1}\right)$ & Day 7 & Day 14 & Day 28 \\
\hline & 0 & $3.06 \mathrm{~b}$ & $3.72 \mathrm{~b}$ & $10.63 b$ \\
\hline & 50 & $3.83 \mathrm{~b}$ & $3.50 \mathrm{~b}$ & $11.05 b$ \\
\hline & 90 & $7.49 a$ & $7.93 a$ & $15.18 \mathrm{a}$ \\
\hline & 130 & $3.40 \mathrm{~b}$ & $3.71 b$ & $8.03 b$ \\
\hline & Significance & $*$ & $*$ & $*$ \\
\hline \multirow{3}{*}{$\begin{array}{l}\text { Chemical fer- } \\
\text { tilizers (CF) }\end{array}$} & $1 / 2 \mathrm{NPK}$ & 3.47 & 3.63 & 11.00 \\
\hline & Full NPK & 5.43 & 5.80 & 11.44 \\
\hline & Significance & ns & ns & ns \\
\hline \multirow{3}{*}{$\begin{array}{l}\text { Cropping } \\
\text { systems (CS) }\end{array}$} & Wheat-mung & 4.41 & 2.24 & 11.66 \\
\hline & Wheat-maize & 4.48 & 7.19 & 10.78 \\
\hline & Significance & ns & * & ns \\
\hline \multicolumn{5}{|l|}{ Interactions } \\
\hline & $\mathrm{BC} \times \mathrm{CF}$ & ns & ns & ns \\
\hline & $\mathrm{CS} \times \mathrm{CF}$ & $*$ & $*$ & $*$ \\
\hline & $\mathrm{CS} \times \mathrm{BC}$ & $*$ & Fig. 2 & ns \\
\hline & $\mathrm{CSxBCxCF}$ & ns & ns & ns \\
\hline
\end{tabular}

The data on net $\mathrm{N}$ mineralization revealed that maximum $\mathrm{N}$ mineralization was obtained where the level of added was $95 \mathrm{t} \mathrm{ha}^{-1}$. The differences between the control (no biochar), lower biochar $\left(50 \mathrm{t} \mathrm{ha}^{-1}\right)$ treatments and the treatment receiving the highest biochar $\left(130 \mathrm{t} \mathrm{ha}^{-1}\right)$ were statistically non-significant during 7,14 and 28 days of incubation periods (Table 4). The reason for lower net $\mathrm{N}$ mineralization in the high biochar treatment could be that the turnover rate of $\mathrm{N}$ may be greater in this treatment due to higher microbial activity as evident in Table 1 , causing lower accumulation of net mineral $\mathrm{N}$ in soil. The differences in net $\mathrm{N}$ mineralization were not remarkable between the $1 / 2$ and full NPK treatments during all incubation periods. Similarly, the net $N$ mineralizations were not significant between the wheat-mungbean and wheat-maize cropping systems during 7 and 28 days of incubation periods. At day 14, the net $\mathrm{N}$ mineralization appeared greater in soil under wheatmaize than wheat-mungbean cropping system.

The interactions between biochar and cropping system were significant for net $\mathrm{N}$ mineralization during 7,14 and 28 days of incubation periods (Table 4). The data revealed that net $\mathrm{N}$ mineralization was greater for wheat-mungbean cropping system where no or lower $\left(50 \mathrm{t} \mathrm{ha}^{-1}\right)$ biochar was applied. At higher biochar doses (90 and $130 \mathrm{t} \mathrm{ha}^{-1}$ ), the net $\mathrm{N}$ mineralization become greater for wheat-maize than wheat-mungbean cropping systems, and this trend was consistent during 7,14 and 28 days of incubation periods. The interactive effects of cropping systems $\mathrm{x}$ mineral fertilizer treatments on net $\mathrm{N}$ mineralization were significant during 7 and 14 days of incubation periods (Table 4). The effect of full NPK treatment on net $\mathrm{N}$ mineralization did not vary considerably under both cropping systems but the effect of $1 / 2$ NPK treatment was remarkable during both 7 and 14 days of incubation periods.

The pattern of $\mathrm{CO}_{2}$ efflux over the 16 days of incubation period showed that the rate of organic matter decomposition was high initially and then declined afterwards. This implies the availability of labile $\mathrm{C}$ in native organic matter and added biochar for microorganisms initially during organic matter decomposition and vanished soon during early days of incubation. Similar pattern in $\mathrm{C}$ mineralization and $\mathrm{CO}_{2}$ efflux has been reported earlier by other researchers such as Fatima et al. (2020) and several others such as Kuzyakov (2011), Zimmerman et al. (2011) and Mason-Jones and Kuzyakov (2017). The results of this study suggest that biochar amendment enhanced $\mathrm{CO}_{2}$ evolution during short-term incubation period (i.e., 16 days). This clearly suggests the availability of labile $\mathrm{C}$ pool in the added biochar which serve as a source of energy that promote microbial activity in the soil. Similar results were also reported by Bruun et al. (2012) and Yin et al. (2014) where $\mathrm{CO}_{2}$ efflux were associated to mineralization of labile $\mathrm{C}$ content of biochar. Wu et al. (2016) and 
Teutscherova et al. (2017) reported that combined application of biochar and compost exerted positive effect on $\mathrm{C}$ mineralization and soil organic matter decomposition. Similar to these results, Deng et al. (2017) also found that soil respiration increased with increasing doses of biochar at least during the first 30 days of incubation period. As in this study, Deng et al. (2017) further showed a decreasing trend in $\mathrm{CO}_{2}$ evolution over time. Fatima et al. (2020) on the other hand found that the biochar-only treatments produced lower or similar $\mathrm{CO}_{2}$ efflux compared with the control treatment and observed inverse relationship to the biochar rates. The biochar and control treatments exhibited similar rate of $\mathrm{C}$ mineralization. Teutscherova et al. (2017) and several other researches have reported low rates of biochar decomposition. These controversies are associated mainly with the pyrolysis temperature. The biochar used in this study was prepared at low pyrolysis temperature and would contain greater amount of labile fraction of $\mathrm{C}$ which could be responsible for greater $\mathrm{CO}_{2}$ evolution than the control. The same was the case with Fatima et al. (2020). It is now clear that biochar which is prepared at temperature contain higher amount of labile $\mathrm{C}$. When such biochar is added to soil, it quickly promotes microbial activity resulting in higher organic matter decomposition (for example, Guo et al., 2020). On the other hand, biochar produced at high pyrolysis temperature are highly stable and the $\mathrm{C}$ is not readily available to microbes resulting in slow organic matter decomposition (for example, Hailegnaw et al., 2019).

It was further observed that the effect of biochar on $\mathrm{CO}_{2}$ efflux varied with the cropping systems. At low biochar (or control) treatment, the $\mathrm{CO}_{2}$ evolution was greater for treatment having mungbean in crop rotation compared with the one having continuous cereals in the rotation, but at high biochar dose, the $\mathrm{CO}_{2}$ evolution was greater in the later than the former crop rotation. This shift in $\mathrm{CO}_{2}$ evolution could be associated with different labile pools of $\mathrm{C}$ in the crop residues. The greater $\mathrm{CO}_{2}$ evolution in the absence of added biochar from mungbean based cropping system could be due to presence of greater amount of labile $\mathrm{C}$ in the mung crop residues.

In the current study, net $\mathrm{N}$ mineralization in the high biochar treatment was lower than the low biochar treatment. As it was observed that microbial activity was higher in the high biochar treatment that could have assimilated most of the mineralized $\mathrm{N}$ leaving behind little mineral $\mathrm{N}$ to accumulate in soil (Prayogo et al., 2014). Reduced net $\mathrm{N}$ mineralization was also observed on other studies (e.g., Tsai and Chang, 2020) which was associated mainly with high $\mathrm{C} / \mathrm{N}$ ratio in biochar. In addition to microbial assimilation of mineral $\mathrm{N}$, biochar may retain the inorganic $\mathrm{N}$ such as ammonium- $\mathrm{N}$ and nitrate- $\mathrm{N}$ on its functional sites (Sanford et al., 2019). Our results suggest that biochar could be used as a strategy to minimize $\mathrm{N}$ losses from the easily available labile $\mathrm{N}$ pools (i.e., $\mathrm{NH}_{4}^{+}-\mathrm{N}, \mathrm{NO}_{3}^{-}-\mathrm{N}$ ) through greater retention in soil. Several researchers have shown the ability of biochar to minimize $\mathrm{N}$ losses which happens as $\mathrm{NH}_{3}$ volatilization, leaching of $\mathrm{NO}_{3}$ and emission as $\mathrm{N}_{2} \mathrm{O}$ (e.g., Li et al., 2020).

In this study, the effect of biochar on net $\mathrm{N}$ mineralization varied with the cropping system. At low biochar dose, the net $\mathrm{N}$ mineralization was greater for wheat-mungbean cropping system. At high biochar level, the net $\mathrm{N}$ mineralization was greater for wheat-maize cropping system. This variation in net $\mathrm{N}$ mineralization could be associated with different $\mathrm{C} / \mathrm{N}$ ratios in crop residues. The $\mathrm{C} / \mathrm{N}$ ratio in mungbean crop residue is generally lower than in maize/ wheat crop residues. The mungbean based cropping system therefore led to greater $\mathrm{N}$ mineralization in the absence of nil or low dose of biochar, whereas maize crop residues with wider $\mathrm{C} / \mathrm{N}$ ratio led to $\mathrm{N}$ immobilization. Kuzyako et al. (2000) reported that $\mathrm{N}$ immobilization dominate over mineralization when the $\mathrm{C} / \mathrm{N}$ ratio of organic matter become higher than 32. Fatima et al. (2020) also reported that higher $\mathrm{C} / \mathrm{N}$ ratio of biochar and wheat straw led to increased $\mathrm{N}$ immobilization.

\section{Conclusions and Recommendations}

This study has shown that biochar amendment enhanced $\mathrm{CO}_{2}$ evolution during short-term incubation period (i.e., 16 days) suggesting the availability of labile $\mathrm{C}$ pool in the added biochar which serve as a source of energy for promotion of microbial activity in the soil. The low net $\mathrm{N}$ mineralization in the high biochar treatment implies that biochar could be used as a strategy to minimize $\mathrm{N}$ losses from the easily available labile $\mathrm{N}$ pools through greater $\mathrm{N}$ retention in soil. In light of results of this study, biochar application is recommended to increase $\mathrm{C}$ and $\mathrm{N}$ sequestration in agricultural soils. 


\section{Acknowledgments}

This study was financially supported by the Agriculture Linkages Program (ALP), Pakistan Agriculture Research Council, Islamabad through a research project No. NR-040. The experiments were carried out at the Department of Soil and Environmental Sciences, The University of Agriculture, PeshawarPakistan. The authors are highly indebted both to the management of ALP/PARC and the University of Agriculture, Peshawar for their support.

\section{Novelty Statement}

Biochar can be used as a strategy to improve microbial activity and $\mathrm{N}$ mineralization in a low fertile alkaline calcareous soil.

\section{Author's Contribution}

Tasneem Shah planned and conducted the experiment, and prepared the paper. Prof. Dr. Muhammad Tariq assisted the author in planning and conducting of experiments and helped in paper write up. Dr. Dost Muhammad assisted the author in lab experiments, lab analysis, statistical analysis of the data and in $\mathrm{pa}^{-}$ per preparation.

\section{Conflict of interest}

The authors have declared no conflict of interest.

\section{References}

Ameloot, N., E.R. Graber, F.G.A. Verheijen and S. De Neve. 2013. Interactions between biochar stability and soil organisms: Review and research needs. Eur. J. Soil Biol., 64: 379-390. https://doi.org/10.1111/ejss.12064

Amonette, J.E., S.S. Dai,Y. Hu, N. Schlekewey, Z. Shaff, C.K. Russell, S.D. Burton and B.W. Arey. 2008. An exploration of the physico-chemical diversity of a suite of biochars. Eos Transactions, AGU 89 (53) Fall Meeting Supplement, Abstract B31G-0379.

Anderson, C.R., L.M. Condron, T.J. Clough, M. Fiers, A. Stewart, R.A. Hill and R.R. Sherlock. 2011. Biochar induced soil microbial community change: implications for biogeochemical cycling of carbon, nitrogen and phosphorus. Pedobiologia, 54: 309-320. https://doi. org/10.1016/j.pedobi.2011.07.005
Barker, B., 2011. Understanding $\mathrm{N}$ mineralization.

Bruun, E.W., P. Ambus, H. Egsgaard, and H. Hauggaard-Nielsen. 2012. Effects of slow and fast pyrolysis biochar on soil $\mathrm{C}$ and $\mathrm{N}$ turnover dynamics. Soil Biol. Biochem., 46: 73-79. https://doi.org/10.1016/j.soilbio.2011.11.019

Cayuela, M.L., M.A. Sánchez-Monedero, A. Roig, K. Hanley, A. Enders, and J. Lehmann. 2013. Biochar and denitrification in soils: when, how much and why does biochar reduce $\mathrm{N}_{2} \mathrm{O}$ emissions? Sci. Rep., pp. 3. https://doi.org/10.1038/ srep01732

Dempster, D.N., D.B. Gleeson, Z.M. Solaiman, D.L. Jones and D.V. Murphy. 2012. Decreased soil microbial biomass and nitrogen mineralization with Eucalyptus biochar addition to a coarse textured soil. Plant Soil., 354: 311-324. https://doi.org/10.1007/s11104-011-1067-5

Deng, W., L.V. Zwieten, Z. Lin, X. Liu, A.K. Sarmah and H. Wang. 2017. Sugarcane bagasse biochars impact respiration and greenhouse gas emissions from a latosol. J. Soils Sediments, 17: 632-640. https://doi.org/10.1007/s11368015-1347-4

Fabbri, D., A.G. Rombolà, C. Torri and K.A. Spokas. 2013. Determination of polycyclic aromatic hydrocarbons in biochar and biochar amended soil.J. Anal. Appl. Pyrolysis, 103: 60-67. https:// doi.org/10.1016/j.jaap.2012.10.003

Fatima, S., M. Riaz, M. Al-Wabel, M. S. Arif, T. Yasmeen, Q. Hussain, M. Roohi, S. Fahad, K. Ali and M. Arif. 2020. Higher biochar rate strongly reduced decomposition of soil organic matter to enhance $\mathrm{C}$ and $\mathrm{N}$ sequestration in nutrient-poor alkaline calcareous soil. J. Soils Sediments. https://doi.org/10.1007/s11368020-02753-6

Guo, K., Y. Zhao, Y. Liu, J. Chen, Q. Wu, Y. Ruan, S. Li, J. Shi, L. Zhao, X. Sun, C. Liang, Q. Xu, and H. Qin. 2020. Pyrolysis temperature of biochar affects ecoenzymatic stoichiometry and microbial nutrient-use efficiency in a bamboo forest soil. Geoderma, 363: 114162. https://doi. org/10.1016/j.geoderma.2019.114162

Hailegnaw, N.S., F. Mercl, K. Pračke, J. Száková, and P. Tlustoš. 2019. High temperature-produced biochar can be efficient in nitrate loss prevention and carbon sequestration. Geoderma, 338: 48-55. http://magazine.topcropmanager. $\mathrm{com} /$ andi $=65592$ andview $=$ articleBrowserand article_id=683899, https://doi.org/10.1016/j. 
geoderma.2018.11.006

Kammann, C., S. Ratering, C. Eckhard and C. Müller. 2012. Biochar and hydrochar effects on greenhouse gas (carbon dioxide, nitrous oxide, and methane) fluxes from soils. J. Environ. Qual., 41: 1052-1066. https://doi.org/10.2134/ jeq2011.0132

Kuzyakov, Y., 2011. How to link soil C pools with $\mathrm{CO}_{2}$ fluxes? Biogeosciences, 8: 523-1537. https://doi.org/10.5194/bg-8-1523-2011

Kuzyakov, Y., J.K. Friedel and K. Stahr. 2000. Review of mechanisms and quantification of priming effects. Soil Biol. Biochem. 32:1485-1498.

Laird, D.A., 2008. The charcoal vision: A winwin-win scenario for simultaneously producing bioenergy, permanently sequestering carbon, while improving soil and water quality. Agron. J., 100: 178-181. https://doi.org/10.2134/ agronj2007.0161

Lehmann, J., M.C. Rillig, J. Thies, C.A. Masiello, W.C. Hockaday and D. Crowley. 2011. Biochar effects on soil biota. A review. Soil Biol. Biochem., 43: 1812-1836. https://doi. org/10.1016/j.soilbio.2011.04.022

Li, Y., G. Feng, H. Tewolde, M. Yang, and F. Zhang. 2020. Soil, biochar, and nitrogen loss to runoff from loess soil amended with biochar under simulated rainfall. J. Hydrol., (In Press). https:// doi.org/10.1016/j.jhydrol.2020.125318

Liu, Y., M. Yang, Y. Wu, H. Wang, Y. Chen, and W. Wu. 2011. Reducing CH4 and CO2 emissions from waterlogged paddy soil with biochar. J. Soils Sediments, 11: 930-939. https://doi. org/10.1007/s11368-011-0376-x

Malghani, S., G. Gleixner and S.E. Trumbore. 2013. Chars produced by slow pyrolysis and hydrothermal carbonization vary in carbon sequestration potential and greenhouse gases emissions. Soil Biol. Biochem., 62: 137-146. https://doi.org/10.1016/j.soilbio.2013.03.013

Mason-Jones K, and Y. Kuzyakov. 2017. Non-metabolizable glucose analogue shines new light on priming mechanisms: triggering of microbial metabolism. Soil Biol. Biochem., 107: 68-76. https://doi.org/10.1016/j.soilbio.2016.12.015

Mulvaney, R.L., 1996. Nitrogen Inorganic forms. In: Methods of soil analysis Part.3- Chemical Methods, ed., D.L. Sparks, 1123-11184. SSSA Book Series No. 5. SSSA, Inc., ASA, Inc., Madison, Wisconsin, USA. https://doi.org/10.2136/ sssabookser5.3.c38
Nelissen, V., T. Rütting, D. Huygens, J. Staelens, G. Ruysschaert, and P. Boeckx. 2012. Maize biochars accelerate short-term soil nitrogen dynamics in a loamy sand soil. Soil Biol. Biochem., 55: 20-27. https://doi.org/10.1016/j. soilbio.2012.05.019

Novak, J.M., W.J. Busscher, D.W. Watts, D.A. Laird, M.A. Ahmedna, and M.A.S. Niandou. 2010. Short-term CO mineralization after additions of biochar and switchgrass to a typic Kandiudult. Geoderma, 154: 281-288. https:// doi.org/10.1016/j.geoderma.2009.10.014

Phillips, C.L., and N. Nickers. 2015. Soil respiration. Reference in earth systems and environmental sciences. https://doi.org/10.1016/ B978-0-12-409548-9.09442-2

Prayogo, C., J.E. Jones, J. Baeyens, and G.D. Bending. 2014. Impact of biochar on mineralisation of $\mathrm{C}$ and $\mathrm{N}$ from soil and willow litter and its relationship with microbial community biomass and structure. Biol. Fert. Soils, 50: 695-702. https://doi.org/10.1007/s00374-013-0884-5

Rondon, M., J. Ramirez, and J. Lehmann. 2005. Greenhouse gas emissions decrease with charcoal additions to tropical soils. In conference proceedings of the $3^{\text {rd }}$ symposium on greenhouse gases and carbon sequestration. 21-24 Mar. 2005. USDA, Baltimore, MA. pp. 208.

Sanford, J.R., R.A. Larson, and T. Runge. 2019. Nitrate sorption to biochar following chemical oxidation. Sci. Total Environ., 669: 938-947. https://doi.org/10.1016/j.scitotenv.2019.03.061

Shafi, M., J. Bakht, M.T. Jan and Z. Shah. 2007. Soil $\mathrm{C}$ and $\mathrm{N}$ dynamics and maize (Zea mays L.) yield as affected by cropping systems and residue management in North-western Pakistan. Soil Till. Res., 94: 520-529. https://doi. org/10.1016/j.still.2006.10.002

Shah, T., Sara and Z. Shah. 2017. Soil respiration, $\mathrm{pH}$ and EC as influenced by biochar. Soil Environ., 36(1): 77-83. https://doi.org/10.25252/ SE/17/51184

Shah, Z., H. Rahman, M.A. Shah, M. Iqbal, U. Pervaiz and Amanullah. 2010. Tillage and residue impacts on microbial biomass and soil $\mathrm{c}$ and $\mathrm{n}$ dynamics under different cropping systems. Pak. J. Bot., 42(3): 1969-1976.

Song, Y., X. Zhang, B. Ma, S.X. Chang, and J. Gong. 2014. Biochar addition affected the dynamics of ammonia oxidizers and nitrification in mi- 
crocosms of a coastal alkaline soil. Biol. Fertil. Soils, 50: 321-332. https://doi.org/10.1007/ s00374-013-0857-8

Steel, R.G.D., J.H. Torriea and D.A. Dickey. 1997. Principle and procedure of statistic. A biometrical approach, $3^{\text {rd }}$ ED. McGraw Hill Book Co. Inc. New York. pp. 172-177.

Teutscherova, N., E. Vazquez, D. Santana, M. Navas, A. Masaguer, and M. Benito. 2017. Influence of pruning waste compost maturity and biochar on carbon dynamics in acid soil: incubation study. Eur. J. Soil Biol., 78: 66-74. https://doi.org/10.1016/j.ejsobi.2016.12.001

Tsai, C.C. and Y.F. Chang. 2020. Nitrogen availability in biochar-amended soils with excessive compost application. Agronomy, 10: 3. https:// doi.org/10.3390/agronomy10030444

Wu, M., X. Han, T. Zong, M. Yuan, and W. Wu. 2016. Soil organic carbon content affects the stability of biochar in paddy soil. Agric. Ecosyst. Environ. 223: 59-66. https://doi.org/10.1016/j. agee.2016.02.033

Yin, Y., X. He, R. Gao, H. Ma, and Y. Yang. 2014. Effects of rice straw and its biochar addition on soil labile carbon and soil organic carbon. J. Integr. Agric., 13: 491-498. https://doi. org/10.1016/S2095-3119(13)60704-2

Zheng, J., C.E. Stewart, and M.F. Cotrufo. 2012. Biochar and nitrogen fertilizer alters soil nitrogen dynamics and greenhouse gas fluxes from two temperate soils. J. Environ. Qual., 41: 13611370. https://doi.org/10.2134/jeq2012.0019

Zimmerman, A.R., 2010. Abiotic and microbial oxidation of laboratory-produced black carbon (biochar). Environ. Sci. Tech., 44: 1295. https:// doi.org/10.1021/es903140c

Zimmerman, A.R., B. Gao and M.Y. Ahn. 2011. Positive and negative carbon mineralization priming effects among a variety of biochar-amended soils. Soil Biol. Biochem., 43: 1169-1179. https://doi.org/10.1016/j.soilbio.2011.02.005 